Vol. 11 (3): 367-370 (2021)

\title{
NORTHERN HEMISPHERE SNOW DEPTH DISTRIBUTION USING OPTIMAL INTERPOLATION
}

\author{
Cezar Kongoli ${ }^{12 *}$, Thomas Smith ${ }^{2}$ \\ ${ }^{1 *}$ Earth System Science Interdisciplinary Center (ESSIC), University of Maryland, College Park, USA; \\ ${ }^{2 *}$ NOAA/NESDIS, College Park, Maryland, USA; \\ *Corresponding Author Cezar Kongoli, e-mail: Cezar.Kongoli@noaa.gov;
}

Received February 2021; Accepted March 2021; Published May 2021;

DOI: https://doi.org/10.31407/ijees11.301

\begin{abstract}
The distribution of snow depth over Northern Hemisphere is investigated by 2-Dimensional Optimal Interpolation applied to synoptic station snow depth measurements. The technique computes at each snow-covered grid point a daily snow depth increment as the weighted average of data increments at surrounding stations and applies it to a first guess snow depth derived from a numerical weather prediction model. Calculation of optimal weights is based on spatial correlation functions of horizontal distance and elevation with fixed e-folding scales of $120 \mathrm{~km}$ and 800 $\mathrm{m}$, respectively. The results obtained indicates that the technique makes substantial improvements in accuracy compared to forecast snow depth especially over high-elevation terrain. The technique also improves estimations over remote poorly monitored areas due to the successful application of a large radius $(600 \mathrm{~km})$ and number of insitu stations for interpolation (50).
\end{abstract}

Keywords: Station Snow Depth, Optimal Interpolation, Snow Depth Analysis 